\title{
First record of the exotic channel catfish Ictalurus punctatus (Rafinesque 1818) (Siluriformes: Ictaluridae) in the Rio dos Sinos basin, RS, Brazil
}

\author{
Sabrina Spindler da Cruz ${ }^{1}$, Mateus Evangelista Leal, \\ Pablo César Lehmann Albornoz ${ }^{2} \&$ Uwe Horst Schulz, \\ ${ }^{1}$ Laboratório de Ecologia de Peixes, Universidade do Vale do Rio dos Sinos - UNISINOS, \\ Av. Unisinos, 950, Cristo Rei, CEP 93022-000, São Leopoldo, RS, Brasil \\ ${ }^{2}$ Laboratório de Ictiologia, Universidade do Vale do Rio dos Sinos - UNISINOS, \\ Av. Unisinos, 950, Cristo Rei, CEP 93022-000, São Leopoldo, RS, Brasil \\ ${ }^{3}$ Corresponding author: Schulz,Uwe Horst, e-mail: uwe@unisinos.br
}

CRUZ-SPINDLER, S., LEAL, M.E., LEHMANN, P.A. \& SCHULZ, U.H. First record of the exotic channel catfish Ictalurus punctatus (Rafinesque 1818) (Siluriformes: Ictaluridae) in the Rio dos Sinos basin, RS, Brazil. Biota Neotrop. 12(3): http://www.biotaneotropica.org.br/v12n3/en/abstract?article+bn01212032012

\begin{abstract}
The introduction of non-native species in inland waters is one of the main threats for aquatic biodiversity. Introduced species may compete for resources, prey on native fauna, spread diseases and parasites. The channel catfish Ictalurus punctatus (Siluriformes, Ictaluridae) was first described by Rafinesque 1818 in the United States and is widely distributed in North America, south Canada and north-east Mexico. This species adapts easily to new environmental conditions, is tolerant to different habitats, and is grown easily in aquaculture, which turns it into a potential invader of natural aquatic environments. The introduction of I. punctatus occurs in Brazil since 1980, and this is the first record of its occurrence in the Rio dos Sinos basin, Brazil. A female adult catfish was captured during a survey in the main channel of the Rio dos Sinos (29 $44^{\prime} 14.04$ " S and $\left.51^{\circ} 05^{\prime} 11.08^{\prime \prime} \mathrm{W}\right)$. Most probably the captured individual is an escapee from nearby aquaculture facilities.
\end{abstract}

Keywords: introduction, exotic species, aquaculture, catfish, environmental laws.

CRUZ-SPINDLER, S., LEAL, M.E., LEHMANN, P.A. \& SCHULZ, U.H. Primeira ocorrência do exótico bagre do canal, Ictalurus punctatus (Rafinesque 1818), (Siluriformes, Ictaluridae) na Bacia do Rio dos Sinos, RS, Brasil. Biota Neotrop. 12(3): http://www.biotaneotropica.org.br/v12n3/pt/abstract?article+bn01212032012

Resumo: A introdução de peixes não nativos em águas interiores é uma das principais ameaças à biodiversidade. Espécies introduzidas podem competir por recursos, predar a fauna nativa, transmitir doenças e parasitas. O bagre americano, Ictalurus punctatus (Siluriformes, Ictaluridae), foi descrito por Rafinesque em 1818 nos Estados Unidos. Possui ampla distribuição na América do Norte, Sul do Canadá, e Nordeste do México. A espécie apresenta alto valor comercial devido ao fato de adaptar-se facilmente a novos ambientes, tolerar variações ambientais, e ser de fácil cultivo. Como todas as espécies exóticas ou alóctones criadas na aqüicultura, é um potencial invasor aos ambientes aquáticos naturais. No Brasil, sua introdução ocorre desde o ano 1980. Este é o primeiro registro de ocorrência de I. punctatus, para a bacia do Rio dos Sinos, São Leopoldo, Brasil. A captura de uma fêmea adulta foi realizada durante um levantamento ictiofaunístico na calha principal do Rio dos Sinos (29॰44' $14.04^{\prime}$ ' S e $51^{\circ} 05^{\prime}$ $\left.11.08^{\prime \prime} \mathrm{W}\right)$. O individuo capturado provavelmente representa o resultado de escape de uma estação de piscicultura. Palavras-chave: introdução, espécies exóticas, aquicultura, bagre, legislação ambiental. 


\section{Introduction}

The deliberate or accidental introduction of species in freshwater systems is an increasing global problem that affects the aquatic biota (Lintermans 2004). Of approximately 1,678 documented introductory events of 280 species of freshwater fish in the world, $70.9 \%$ resulted in the establishment of the species in the new environment (Bomford et al. 2010). The introduction or transference of exotic and/or allochthonous species can result in the decline or extinction of native species (Rahel 2000). Introduced species can be vectors for pathogens and parasites, and usually are competitors for resources and areas for reproduction and may alter the aquatic environment (Welcomme 1988, Agostinho et al. 2000).

Some species are cited in lists or databases like the national database for non-native invasive species, established by the Instituto Hórus and The Nature Conservancy in cooperation with the Ministry of Environment and associated members from all over Brazil. These non-native species are generally introduced for aquaculture, biological control, sport fishing, released by aquarists, by accident (Ligas 2007). The introduction of nonnative species can be used to compensate the decline of natural fish stocks or to occupy a "vacant niche" in newly created artificial ecosystems like reservoirs (Elvira \& Almodóvar 2001).

The Brazilian Federal Law 9605-98 determines punishement of up to three years of reclusion for unauthorized introductions of exotic especies. Nevertheless, as in a completely contradictory way, the polycultural farming of commercial species such as tilapia (Oreochromis niloticus niloticus and Tilapia rendalli; Cichlidae) and grass carp (Ctenopharyngodon idella; Cyprinidae) is encouraged, even by state agencies. As recorded by FEPAGRO (Mardini et al. 1997) more than $90 \%$ of the established commercial cultivations of the Rio Grande do Sul state are of exotic species, several of which are frequently recorded in inventories of fish assemblages in southern Brazil (Mardini et al. 1997, Schulz \& Leal 2005, Leal et al. 2009, Winckler-Sosinski et al. 2009, Leal et al. 2010).

The Ictaluridae belong to the Siluriformes and contain nine species, including Ictalurus punctatus Rafinesque (1818). The channel catfish is one of the most important freshwater species commercialized in the United States (FISHBASE http://fishbase. org; accessed 05/2010). Its natural distribution includes the states around the Gulf of Mexico and the Mississippi Valley/USA (Nelson 1994). Today it is introduced in provinces of Canada and other parts of the United States, as well as in many other countries in the world (Wellborn 1988).

Ictalurus punctatus lives in lotic and lentic environments and reaches sexual maturity at two years of age. The species spawns naturally in lentic systems, mainly in structurally complex environments containing rocks and logs, where it takes care of the offspring (Wellborn 1988). Juveniles are omnivorous, feeding on insects, mollusks, algae and fish. Adults feed predominantly on fish and occasionally on small birds (Wellborn 1988, Goldstein \& Simon 1999). Fast growth, high fecundity, euryphagy, resistance against extreme environmental conditions, as well as advances in artificial reproduction, rearing and fattening, are factors that boost its commercial exploitation (Ligas 2007).

Brazil seems to be highly vulnerable to the invasion and proliferation of the channel catfish (Orsi \& Agostinho 1999, Vitule et al. 2006, 2009). The occasional captures of I. punctatus in south Brazilian inland waters have been occurring frequently since the year 2008, although these events are underrepresented in scientific literature. In the state of Rio Grande do Sul, Brazil, there are two records of this species in the ichthyological collection of the Museum of Science and Technology, Catholic University of Rio Grande do
Sul (PUCRS), originated from the Taquari River at the mouth of the Rio Guaporé, Taquari-Antas river basin (MCP 43066 and 43352).

Considering the characteristics of fast adaptation to new environments and its potential as predator, the channel catfish could possibly change the equilibrium of the aquatic biocenosis of natural systems. Therefore, the present study aims to report the first record of I. punctatus in a natural environment in the Rio dos Sinos basin, Rio Grande do Sul, Brazil.

\section{Materials and Methods}

The study was conducted in the Rio dos Sinos basin, which is part of the Laguna dos Patos system (Fundação... 2009). The specimen was captured with a gillnet $(25 \mathrm{~mm}$ mesh size between adjacent knots). The net was set in the main channel of the river in the city São Leopoldo (29 44' 14.04" S and 51 ${ }^{\circ} 05^{\prime} 11.08^{\prime}$ " W) (Figure 1).

The collected catfish was anesthetized with Eugenol and preserved in $10 \%$ formalin. In the Laboratory of Ichthyology - UNISINOS the fish was identified based on material provided by Britski et al. (1999) and Graça \& Pavanelli (2007). The specimen was deposited in the fish collection of the Museum of Science and Technology of the Catholic University of Rio Grande do Sul (MCP 46292).

\section{Results}

A mature female specimen of I. punctatus $(36.5 \mathrm{~cm} \mathrm{SL}$ and 419.9 g; Figure 2) was captured on October 21, 2009 in $3.5 \mathrm{~m}$ water depth. The stomach content of the specimen was analyzed and contained four partly digested insects (Hymenoptera) and remains of plant material. Together with I. punctatus two other species considered as invasive (allochthonous) were captured: Pachyurus bonariensis (Sciaenidae), commonly known as La Plata croaker, and Acestrorhynchus pantaneiro a piscivcorous characin (Acestrorhynchidae).

\section{Discussion}

The channel catfish is often confounded with the native silver catfish jundiá (Rhamdia quelen, Heptapteridae). The more obvious morphological difference between both species is the number and distribution of the barbels. The native silver catfish has three pairs of barbels (two mentonian and one maxillary), whereas the exotic channel catfish has four (two mentonian, one maxillary, and one nasal) (Wellborn 1988). Another important characteristic of the exotic species is the first ray of the dorsal fin, which is transformed in a rigid spine, whereas in the silver catfish it is soft.

The collected specimen was a mature female, which indicates that the reproduction of this species in the Rio dos Sinos is plausible. The spawning season of the channel catfish under natural conditions in North America occurs during the summer at elevated water temperatures (Wellborn 1988). A similiar range of conditions occurs in the Rio dos Sinos.

Invasive species can compete for food resources with native species (Welcomme 1988, Agostinho et al. 2000). Piedras et al. (2006) reported strong similarities comparing the digestive systems of the invasive I. punctatus and the two native siluriforms, R. quelen and Pimelodus maculatus, which indicates a strong overlap in the food niches of these three species. In this sense, the sympatric occurrence of the channel catfish with the native species may result in interspecific competition for the same food resources.

Aquaculture is becoming one of the major vectors for the introduction of exotic species (Welcomme 1988). The proximity and access to water resources are the reasons for the instalation of fish farms in river floodplains, or directly in the river channel or in marginal ponds (fish cages). These areas are highly susceptible to flooding. On these ocasions thousands of juvenile and adult fish may escape (Orsi \& Agostinho 1999; Leal et al. 2010). A severe flood 


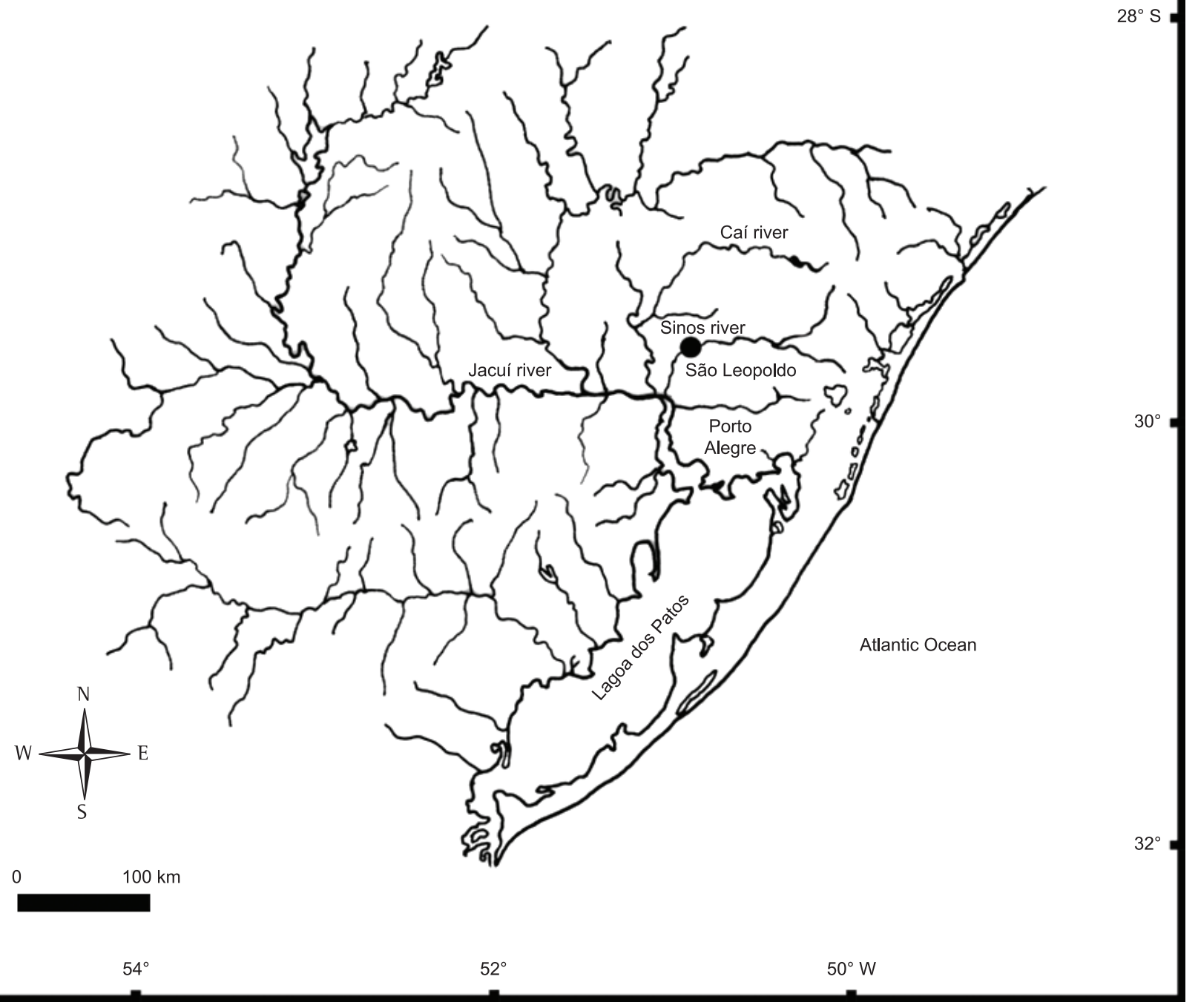

Figure 1. Map of Rio dos Sinos basin; the black dot indicates the capture site of Ictalurus punctatus $\left(29^{\circ} 44^{\prime} 14.04^{\prime \prime} \mathrm{S}\right.$ and $51^{\circ} 05^{\prime} 11.08^{\prime \prime} \mathrm{W}$ ).

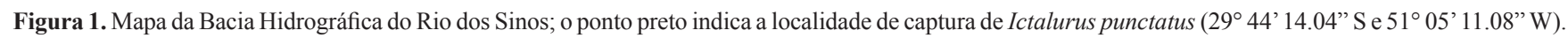

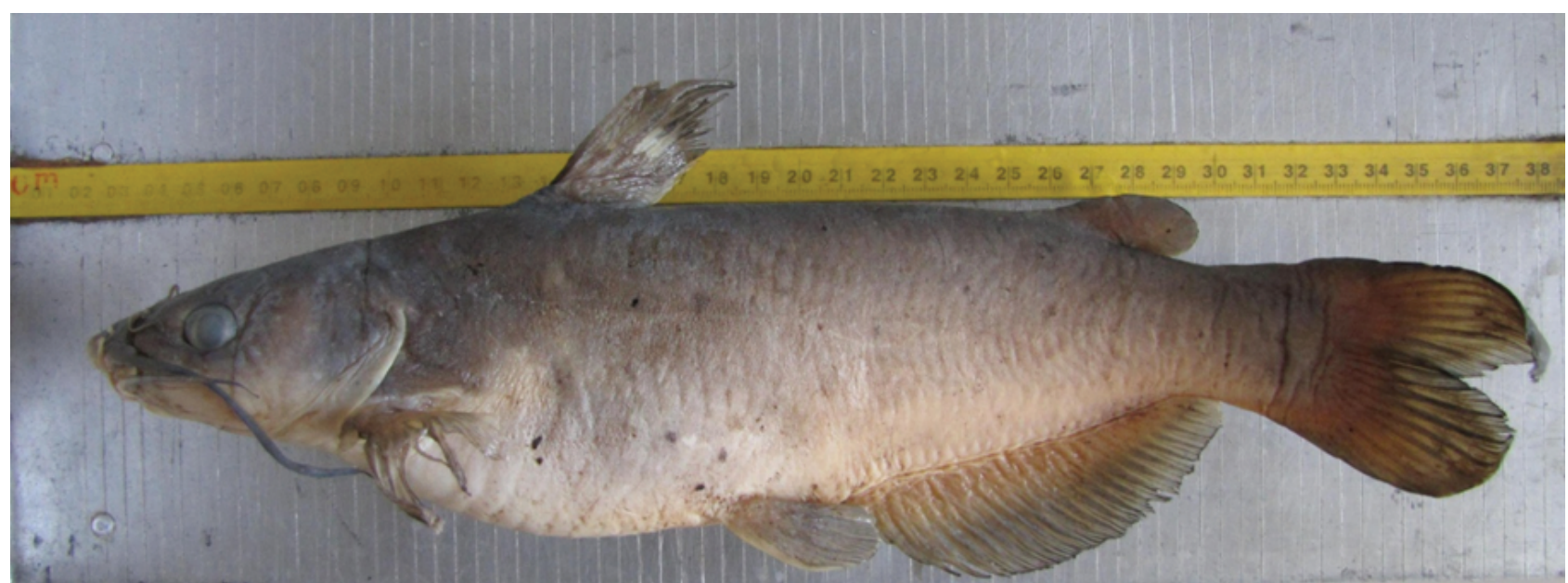

Figure 2. Captured specimen of Ictalurus punctatus (MCP 46292).

Figura 2. Exemplar coletado de Ictalurus punctatus (MCP 46292). 
ocurred in the Rio dos Sinos in May 2008 and may have resulted in an escapee of the captured channel catfish from one of the nearby fishfarms.

Former studies of the fish fauna of Rio dos Sinos have shown the vulnerability to the invasion of the basin by non-native species. Leal et al. (2009) state that of the 102 species currently registered in Rio dos Sinos 10\% are non native fishes. The capture of the allochthonous characin Hoplerythrinus unitaeniatus (Erythrinidae) infected by the also non-native parasite crustacean Lernaea cyprinacea (Copepoda) corroborate the hypothesis of fish farm escapees. In fact, the specimen of Ictalurus puncatus was captured in the same location where $H$. unitaeniatus was found (Leal et al. 2010).

The channel catfish is a successfully introduced and cultivated species due to the easy reproduction in captivity and ability to adapt to new environments. According to the FAO (Food... 1997), the channel catfish is one of the most frequently introduced fish in the list of exotic species in Brazil. In the Rio Grande do Sul state the environmental protection agency FEPAM (Fundação Estadual de Proteção Ambiental Henrique Luiz Roessler/RS), based in a Federal law (Portaria 145, 29 October 1998 - IBAMA), imposes legal restrictions to the propagation of exotic species in aquaculture. However, more than one million fingerlings of several exotic species are still grown and commercialized annually by fish farmers in the state (Vermulm Junior \& Giamas 2011).

The capture of one individual of I. punctatus is not enough evidence to characterize a successful invasion; nevertheless, it should alert managers to the potential impact of fish introductions on the native ichthyofauna. The use of exotic fishes in Brazilian aquaculture is highly questionable, considering the high native fish diversity and its potential for cultivation. Just to mention an example, the native silver catfish Rhamdia quelen may substitute the channel catfish in aquaculture, minimizing the risks of ecological problems of eventual escapees.

\section{Acknowledgements}

We are grateful to FAPERGS-Probic for the scientific initiation scholarship for Sabrina Spindler and to UNISINOS for encouraging this research. An unknown referee contributed significantly to the final version of the manuscript.

\section{References}

AGOSTINHO, A.A, JÚLIO JUNIOR, H.F. \& TORLONI, C.E.C. 2000 Impactos causados pela introdução e transferência de espécies aquáticas: uma síntese. In VII Simpósio brasileiro de aquicultura. FEALQ, Piracicaba, p.59-75.

BOMFORD, M., KRAUS, F., BARRY, SC. \& LAWRENCE, E. 2010. Predicting establishment success for alien reptiles and amphibians: a role for climate matching. Biol. Invasions. 11:713-724.

BRITSKI, H.A., DE SILIMON, K.Z.S. \& LOPES, B.S. 1999. Peixes do Pantanal: Manual de identificação. Embrapa, Brasília, 184p.

ELVIRA, B. \& ALMODÓVAR, A. 2001. Freshwater fish introductions in Spain: facts and figures at the beginning of the 21 st century. J. Fish. Biol. 59(Suppl. A):323-331. http://dx.doi.org/10.1111/j.1095-8649.2001. tb01393.x

FOOD AND AGRICULTURE ORGANIZATION OF THE UNITED NATIONS - FAO. 1997. Aquaculture development. FAO, Rome, 82 p. FAO Technical Guidelines for responsible fisheries, n.4.
FUNDAÇÃO ESTADUAL DE PROTEÇÃO AMBIENTAL HENRIQUE LUIS ROESSLER - FEPAM. 2009. Qualidade Ambiental. Região Hidrográfica do Guaíba. http://www.fepam.rs.gov.br/qualidade/guaiba. asp. (último acesso em 12/10/2009).

GOLDSTEIN, R.M. \& SIMON, T.P. 1999. Toward a united definition of guild structure for feeding ecology of North American freshwater fishes. In Assessing the sustainability and biological integrity of water resources using fish communities (T.P. Simon, ed.). CRC Press, Boca Raton, p.123-138.

GRAÇA, W.J. \& PAVANELLI, C.S. 2007. Peixes da planície de inundação do Alto rio Paraná e áreas adjacentes. Eduem, Maringá, 241p.

LEAL, M.E., BREMM, C.Q. \& SCHULZ, U.H. 2009. Lista da Ictiocenose da Bacia do Rio dos Sinos, Sul do Brasil. B. Inst. Pesca (Online).

LEAL, M.E., KLEIN, G.F., SCHULZ, U.H. \& LEHMANN, P. 2010 Primeiro registro e aspectos ecológicos de Hoplerythrinus unitaeniatus (Agassiz, 1829) (Characiformes, Erythrinidae) como espécie introduzida na Bacia do Rio dos Sinos, RS, Brasil. Biota Neotrop. 10(3): http://www. biotaneotropica.org.br/v10n3/pt/abstract?article+bn00710032010.

LIGAS, A. 2007. Population dynamics of the Channel Catfish, Ictalurus puncatatus (Rafinesque, 1818), in the Ombrene river (Tuscany, Italy). Atti Soc. tosc. Sci. nat., Mem., Serie B, 114.

LINTERMANS, M. 2004. Human-assisted dispersal of alien freshwater fish in Australia. New. Zea. J. Mar. Fresh. 38:481-501.

MARDINI, C.V.; RANGEL, M.F.S. \& DA SILVA, T.M.A. 1997. Caracterização preliminar do perfil da piscicultura desenvolvida no Rio Grande do Sul. Porto Alegre,18p. Boletim da Fepagro, n.6.

NELSON, J.S. 1994. Fishes of the world. 3th ed. New York, John Wiley \& Sons, Inc., 600p.

ORSI, M.L. \& AGOSTINHO, A.A. 1999. Introdução de espécies de peixes por escapes acidentais de tanques de cultivo em rios da Bacia do Rio Paraná, Brasil. Rev. Bras. Zool. 16(2):557-560. http://dx.doi.org/10.1590/ S0101-81751999000200020

PIEDRAS, S. R. N., POUEY, J.L.O.F \& MORAES, P.R.R. 2006. Comportamento alimentar e reprodutivo de peixes exóticos e nativos cultivados na zona sul do Rio Grande do Sul. Rev. Bras. Agroc. 3(12):341-244.

RAHEL, F.J. 2000. Homogenization of fish faunas across the United States. Science. 288:854-856. http://dx.doi.org/10.1126/science.288.5467.854

SCHULZ, U.H. \& LEAL, M.E. 2005. Growth and mortality of black bass, Micropterus salmoides (Pisces, Centrachidae; Lacapede 1802) in a reservoir in South Brazil. Braz. J. Biol. 65(3):124-130.

VERMULM JUNIOR, H. \& GIAMAS, M.T.D. 2011. Algumas considerações sobre a Ictiofauna do Alto Rio Paraná. Textos Técnicos do Instituto de Pesca de São Paulo. http://www.pesca.sp.gov.br/textos_tecnicos.php (último acesso em 02/12/2011).

VITULE, J.R.S., UMBRIA, S.C. \& ARANHA, J.M.R. 2006. Introduction of the African catfish Clarias gariepinus (Burchell, 1822) into Southern Brazil. Biol. Invasions. 8:677-681.

VITULE, J.R.S. 2009. Introduction of fishes in Brazilian continental ecosystems: Review, comments and suggestions for actions against the almost invisible enemy. Neo. Biol. Cons. 4(2):111-122.

Welcomme, R.L. 1988. International introductions of inland aquatic species. Fao Fish Tec Pap, Roma. 294 p.

WELLBORN, T.L. 1988. Channel Catfish - Life History and Biology. Southern Regional Aquaculture Center, n.180.

WINCKLER-SOSINSKI, L., SCHWARZBOLD, A. \& SCHULZ, U.H. 2009. Fish assemblage structure in altitude rivers under the effect of exotic species introduction, north east of Rio Grande do Sul, Brazil. Acta Limnol. Bras. (21):473-482. 